\title{
Identification of carcinoma embryonic antigen release mechanism Carcinoembryonic Antigen (CEA) from the surface of colorectal cancer cells
}

\author{
Shahin Asadi*, Mahsa Jamali and Hamideh Mohammadzadeh \\ Young Researchers and Elite Club, Tabriz, Branch, Islamic Azad University, Tabriz, Iran
}

\begin{abstract}
Background and aim: Carcinoembryonic antigen (CEA) carcinoembryonic antigen is one of the tumor markers that is expressed in many colorectal, stomach, pancreatic, lung and chest cancers. The exact mechanism for releasing this antigen from the cell surface to the cancer patients is still unknown. Carcinoma-embryonic antigen proteins are bound to a cell membrane through a glycosyl-phosphate tidal inositol (GPI-anchor) linkage. There is evidence that specific phospholipase enzymes interfere with the breakdown of GPI binding and the removal of CEA from the cell surface. Considering these evidence and data, we investigated the probable role of glycosyl phosphatidyl inositol phospholipase (GPI-PLD) D in hydrolysis and the release of carcinoma amniobiline antigens. Materials and methods: In this study, we demonstrated the expression of GPI-PLD in some cell lines of adenocarcinoma of colorectal using RT-PCR. The level of carcinogenic amniotic antinase released by one of the cancer cell lines (LS-180), which freely releases large amounts of carcinoma ambrionic antigen in the culture medium, was detected in the presence and absence of specific inhibitors and activators of this enzyme.
\end{abstract}

Results: The expression of the gene by RT-PCR showed that GPI-PLD was expressed in these cells. Also, the amount of CEA protein in the culture medium increases or decreases in the presence and absence of specific inhibitors and activators of this enzyme.

Conclusion: According to the results, we found evidence of the role of the GPI-PLD enzyme present in these cells as an effective enzyme for the release of carcinoma ambrionic antigen.

\section{Introduction}

Carcinoembryonic Antigen (CEA) Carcinoembryonic Antigen is one of the most commonly used tumor markers. The amount of this antigen increases in many cancerous diseases such as colon cancer, breast, lung, prostate and stomach, as well as gynaecological malignancies. The level of this serum antigen is very variable in different patients. In some cancer patients, despite the expression of carcinomaembryonic antigen in tumor tissue, its serum levels are normal [1-3].

The carcinoma ambrionic antigen protein structure consists of a V-like Ig domain domain at the end of the amine, along with six I-like Ig domain regions, and ends with a hydrophobic sequence at the end of the carboxylation. This area, which contains 26 amino acids, is processed and connected to a cell membrane by a glycoprotein (GPI anchor) section [4]. The normal performance of the carcinogenic embryonic antigen and its association with the onset of cancer is uncertain. It has been shown that the release of this antigen from many colon tumors is associated with the progression of cancer and malignancy [5]. Some of the roles of CEA include participation in inter-cellular homophilic and heterophilic adhesions [6] and possibly contributing to cancer [7]. Carcinoma ambrionic antigen also plays a role in liver metastasis from colon cancer [8,9], which is most likely due to stimulation of Kupffer cells by soluble antigen and cytokine production $[8,10]$.

Although it has long been known that the autoantibody carcinoma of the antigen is secreted from the cell surface, the exact mechanism for releasing it from the cell surface to the inside of the serum is still unknown. Tri-X-114 experiments showed that its secretion form was hydrophilic and was placed in an aqueous phase, while the membraneattached form exhibited more hydrophobic property, it is shown that CEA secretion, lacking. The hydrophobic section of the GPI is [11]. Khan and Hammarstrom showed that the carcinoma embryonic antigen that has been isolated in isolated membranes and membrane fragments, not in healthy cells, can be cleansed by the human serum or GPI-PLD [12]. Studies have also shown that CEA is released in a nonproteolytic incision, and possibly by an endogenous phospholipase, in normal colon epithelial cells and in colon cancer cells [13]. GPI-PLD androgen responsible for cutting and releasing GPI proteins from their anchorages at the cell surface [14-16]. The cDNA has been cloned with a GPI (GPI-PLD) specific phospholipase [17] and expressed in a number of human tissues, including pancreatic beta cells, macrophages, keratinocytes, and liver cells [18]. New studies suggest that GPI-PLD is responsible for cutting and releasing a number of GPI proteins from a variety of cells, such as tumor cells [16-19], and so we are investigating the role of this enzyme in releasing carcinoma-embryonic antigens from the surface Colorectal carcinoma cells.

Correspondence to: Shahin Asadi, Young Researchers and Elite Club, Tabriz, Branch, Islamic Azad University, Tabriz, Iran, Tel: +989379923364, E-mail: shahin.asadi1985@gmail.com

Key words: Carcinoma Ambriotic Antigen (CEA), GPI-PLD, Glycosyl Phosphatidyl Inositol Compound

Received: July 20, 2017; Accepted: August 15, 2017; Published: August 17, 2017 


\section{Analyzation method}

\section{Materials}

Guanidium thiocyanate, sodium citrate, phenol, and 10 and 1-phenanthrolin (PNT) from Fluka chemical company (Switzerland), L-glutamin, BSA, Suramin and DMEM from Sigma (USA). Random Primer, Agarose MP and dNTPs from Roche (Germany), preparation of Penicillin, Streptomycin, Ribonuclease inhibitor, M-MuLV reverse transcriptase, Taq DNA polymerase, and DNA markers and oligonucleotide biosynthesis primers by Fermentas (Lithuania).

FBS from Biochrom (Germany) and the CEA ELISA kit from CanAg CEA EIA Kit (Sweden). Human cell carcinoma cell lines including LS-180, HT-29, HT-29/219 and SW749 lines were prepared from the International Bank of Iran Cell, Pasteur Institute, Tehran (NCBI, Pasteur Institute, Tehran). Purchasing cells and flasks from NUNC (Denmark) and all chemicals from Merck (Germany) were made.

\section{Cell culture}

Cell lines LS-180, HT-29, HT-29/219 and SW749 were cultured in T25 and T75 cell culture flasks. The culture conditions included a DMEM medium containing 10\% FBS, $100 \mathrm{ng} / \mathrm{ml}$ penicillin $/ 100 \mu \mathrm{g} / \mathrm{ml}$ streptomycin and mM 2 L-glutamine. The cells were stored at $37{ }^{\circ} \mathrm{C}$ and the wet atmosphere with $5 \% \mathrm{CO}_{2}$.

Measurement of Carcinoma Ambionic Antigen Released from Multiple Cell Carcinoma Celllines 40,000 cells of cell lines of carcinoma of the colon were cultured in 4 house plates of $2 \mathrm{~cm}$ in diameter per house.

The cells were grown in a single layer in $250 \mu$ of serum medium until the entire bottom of the plate was covered. Under these conditions, the culture medium was removed to study the release of carcinoma ambrionic antigen in the stagnant phase and replaced by a serum-free enzyme and incubation continued for 96 hours. The culture was discarded every 48 hours and for centrifugation at $\times 3000 \mathrm{~g}$ for 5 minutes, until any evacuated cell was removed, then the medium was transferred to a new tube and transferred to a new tube for a further 20 minutes at a temperature of $\times 10000^{\circ} \mathrm{C}$ and a C4 ${ }^{\circ} \mathrm{C}$ centrifuge. To, remove cellulose and cellular vesicles, the culture medium was stored at $-70^{\circ} \mathrm{C}$ to allow CEA release to be measured by ELISA kit and according to the instructions. When the flask was filled, the total protein was removed. This is done by adding $\mathrm{L} \mu 600$ Lysis buffer (10 $\mathrm{mM}$ Tris $\mathrm{pH} 7.0,1 \%$ SDS) at boiling temperature to the cells cultured in the plates and then removing them from the bottom of the plate. The amount of carcinoma amniotic protein released from the viral cells of the cell, measured in terms of ng of antigen per mg of serum protein, was normalized and its concentration was measured by Bradford [20] and Crystallin BSA as standard. Effect of Surinam, 10, 1-Phenantrolin and EDTA on the release of carcinogenic ambrionic antigen Soramins were prepared as sterile stoichiometric concentrations of $100 \mathrm{mg} / \mathrm{ml}$ in distilled water and stored at $-20^{\circ} \mathrm{C}$. PNT was stored in a serum-free medium at a concentration of $250 \mu \mathrm{g} / \mathrm{ml}$ and stored at $-4^{\circ} \mathrm{C}$ until use. To investigate the effect of sulamine and phenanthraine on the release of carcinoma ambrionic antigen, simultaneously two LS-180 cells were cultured in 4-well plates (cells/well 200000 in $250 \mu \mathrm{l}$ culture media) and allowed the cells to sub-confluence stage Grow up. At this stage, the cells were washed twice with PBS and then incubated in fresh DMEM medium, which contained both FBS-free series with sulamine or phenanthraine. Soramine was used in doses of 50 and $100 \mu \mathrm{g} / \mathrm{ml}$ and phenanthroline at a dose of $2 \mu \mathrm{g} / \mathrm{ml}$ and in two conditions with $12 \mu \mathrm{M}$ of $\mathrm{ZnCl}_{2}$. The cells were kept in a humidified incubator at $37^{\circ}$
C for a period of 8 to 2 hours. Control conditions include cell culture in a culture free of these chemicals. The culture medium of both plates was collected once every two hours of incubation. In order to, remove any cell residue, the culture medium was centrifuged according to the instructions. At the end, the number of live cells per plate house was counted by Trypan Blue and the use of Neubarb Lam. The amount of carcinogenic embryonic release of antigen in the culture medium was measured by ELISA method. The effect of EDTA on the release of this antigen was also observed. In summary, $106 \times 1$ cells of Ls-180 were cultured in plates of $6 \mathrm{~cm}$ to the sub-confluency stage. Then, the cells were incubated in $\mathrm{mL} 2$ fresh media and concentrations of 10 and 25 EDTA for 2-4 hours and the amount of antigen released was measured according to the above method. The results in this article are the mean values obtained from each of the two separate cultivations.

\section{RNA extraction and RT-PCR}

The total RNA of the cell was extracted from sub-confluent cells and isolated by guanidium thiocyanate acid and according to the instructions of Chomczynski and Sacchi [21]. The cDNA was prepared using Reverse Transcription (RT) and using $5 \mu \mathrm{g}$ of Total RNA, primers $\mathrm{Pd}(\mathrm{N}) 6$ random hexamer primer and M-MuLV Reverse Transcriptase in $20 \mu \mathrm{L}$ of reaction solution and in accordance with the instructions. PCR in $\mu \mathrm{L} 50$ of the reaction mixture containing $\mu \mathrm{L} 10$ from the RT reaction, $1.5 \mu \mathrm{g}$ DNA polymerase enzyme, $0.2 \mathrm{mM}$ dNTPs, and $0.5 \mu \mathrm{M}$ of each of the forward and reverse primers in $\times$ PCR 1 of the reaction buffer, which Was provided by the company producing Taq enzyme. The sequence of primers used for GPI-PLD, carcinoma ambrionic antigen and -actin $\beta$ (internal control) are shown in Table 1. The reaction mixture was denatured for 5 minutes at a temperature of $94^{\circ} \mathrm{C}$ and amplified during 35 cycles, each cycle containing 1 minute denaturation at $94^{\circ} \mathrm{C}$, annealing 45 seconds at $62^{\circ} \mathrm{C}$, and 45 seconds polymerization at $72^{\circ} \mathrm{C}$.

\section{Statistical methods}

Statistical data were analyzed by SPSS software and statistical differences between groups were studied by tukey HSD multiple comparison test.

\section{Findings}

Timing of Carcinoma Ambionic Antigen Releasing from Colon Carcinoma Cells We first compared the release of carcinogenic embryonic antigens from different colon carcinoma lines to the culture medium as a function of time [22-25]. The release of CEA was investigated in four different cell lines of Ls-180, HT-29, HT-29/219 and SW742 in the exponential phase and stationary phase (which cells were in a serum-free environment under confluency conditions).

Figure 1: Timing of Carcinoma Immunization of Antigen from Different Cellular Cellular Carcinoma Lines.

The culture medium of these cells was collected every 48 hours and its CEA level, as in the text. Come, measured. In each curve, the last

Table 1. The sequence of primers used for RT-PCR amplification.

\begin{tabular}{|l|l|}
\hline Gene & Primer sequence \\
\hline GPI-PLD & Sense: 5'GGACACAGGGCTCTGGAGTTTCT3' \\
\hline & Antisense: 5`AACTGGCTCAACACGTCTCCTCC3' \\
\hline CEA & Sense: 5'TTCACCTGTGAACCTGAGGC3' \\
\hline & Antisense: 5'AGAGACTGTGATGCTCTAGACTATGGA3' \\
\hline B-Actin & Sense: 5'CCACGAAACTACCTTCAACTCC3' \\
\hline & Antisense: 5'TCATACTCCTGCTGCTTGCTGATCC3' \\
\hline
\end{tabular}


two points represent the amount of antigen released in the serum-free enzyme.

\section{Diagnosis of GPI-PLD expression and carcinogenic embryonic antigen by RT-PCR}

In these four cell lines of the carcinoma, expression of this antigen, GPI-PLD and -actin $\beta$ (internal control) was determined by RT-PCR. The results of this RT-PCR are shown in Figure 2. As seen in the figure, in all four cell lines, the carcinoma ambrionic antigen and GPI-PLD mRNA provide a DNA product with predicted values of $465 \mathrm{bp}$ and $416 \mathrm{bp}$.

\section{Pay attention to this}

It is important to note that in the SW742 cell line, a more compact band is observed.

\section{M: Marker and C: Negative Control.}

The effect of GPI-PLD activator on the release of carcinogenic embryonic antigens Without this chemical, it was used as a control. The test results show the standard mean error in two independent studies. Statistical differences between groups by tukey HSD multiple comparison test.

\section{Effect of GPI-PLD inhibitor on carcinogenic embryonic secretion of antigen}

The effect of EDTA on the release of carcinoma ambrionic antigen: As shown in Figure 1, the serum-free medium releases less CEA than the serum medium. However, the autoimmune release of the carcinoma ambrionic antigen in the serum-free medium did not decrease after 4 days (The last two points in Figure 1, which indicates that an endogenous enzyme and not a serum enzyme are responsible for catalyzing the release of cells. Cells for active growth require growth factors that are provided by the FBS in the environment. Reducing the release of carcinogenic embryonic antigen by Ls- 180 cells in serum-free conditions may be due to lower cellular metabolism and lower protein biosynthesis. Previous studies have shown that CEA-soluble in the medium does not contain the inositol glycane section [12]. SDS-PAGE analysis of the culture medium of these cell lines as well as previous studies have shown that the carcinoembrane protein of the released

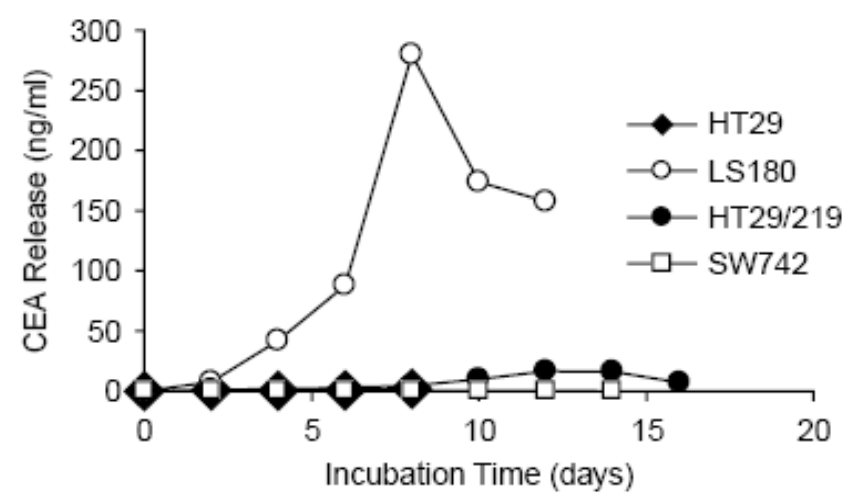

Figure 1. Compares the release time of the carcinogenic embryonic antigen from these lines. The amount of antigen release released from the cells reaches its peak in the confluency phase and decreases in the serum-free medium. There is a large difference in CEA levels from different lines. The cell lines of the strong producer, the Ls-180 and HT29/219, in confluency and within 48 hours, released 46 and 3/9 carcinoembryonic antigens per gram of total cell protein, respectively, while cells. The weak producer, SW742 and HT-29, released 0.4 and $0.2 \mu \mathrm{g} / \mathrm{ml}$, respectively. antigen has the same molecular weight of the membrane-bound healthy form (KD $180 \sim$ ). Sack et al., Also showed that this cell surface antigen is resistant to cut by various proteases [26]. These observations reject the hypothesis of releasing carcinogenic ambrionic antigens from the cell surface via proteases.

\section{Diagnosis of GPI-PLD expression and carcinogenic embryonic antigen by RT-PCR}

The expression of a specific GPI (GPI-PLD) phospholipase and its necessity to cut certain GPI-anchored proteins has been shown in many normal and human cancer cells [27]. As the above experiments clearly show, these four cancer cell lines differ in their degree of CEA release. Therefore, we decided to simultaneously examine the expression of the carcinoma ambrionic gene and GPI-PLD gene in these cells. In these four cell lines of the carcinoma, expression of this antigen, GPI-PLD and -actin $\beta$ (internal control) was determined by RT-PCR. As shown in Figure 2, in each of the four cell lines, the carcinoma embryonic antigen and GPI-PLD mRNA provide a DNA product with predicted values of $465 \mathrm{bp}$ and $416 \mathrm{bp}$. This product is not due to infection with genomic DNA, because both primers are designed in different exons, also, in the control tube, with the removal of the RT stage, the DNA amplification decreased (negative control in Figure 2). RT-PCR is not a quantitative assay, but a comparison of the four band bands associated with all cells showed that the CEA band in the SW742 line is clearly less compact than other bands. This reduction in expression is clearly indicated by the expression -actin $\beta$ (750 bp band in Figure 2). Given that we used the same total RNA and the same reaction conditions for each of the four lines, it seems that at least SW742 expresses a relatively small amount of carcinogenic ambrionic antigen in comparison with other cell lines. Using RT-PCR as a result of the use of total RNA instead of mRNA, indicates that GPI-PLD expression in these tumor cell lines is high.

\section{The effect of GPI-PLD activator on the release of carcinogenic embryonic antigens}

To investigate the possible role of GPI-PLD in the autoimmune release of the carcinoma-embrionic antigen from these cells, we decided to study the effect of surfine and 10,1-phenanthraine, which are active agents and GPI-PLD inhibitors, respectively. GPI-PLD enzyme activity is often used to detect cellular systems. To do this, cell lysate is used as a source for the GPI-PLD enzyme and the GPI-anchored radio labeled protein, for example, VSG (variant surface glycoprotein) as a substrate [28]. This method is difficult and time-consuming. Therefore, as another solution, we investigated the effect of GPI-PLD activator and inhibitor on the release of carcinogenic embryonic antigen from healthy cells. This study was performed on Ls-180 cells, because CEA release from this line is high and therefore, it will be easier to study the product of GPI-PLD reaction with non-radioactive method to detect this antigen. Soramine is a polysulfonate naphthyl urea, which increases in GPI-PLD activity in in vitro studies [29,30]. The Ls-180 cultures were subjected to sub-confluency, were constantly exposed to Soramins at concentrations of $50 \mu \mathrm{g} / \mathrm{ml}$ and 100 in the medium with and without serum for 8 hours. The culture medium was collected every 2 hours, and its CEA value was measured. The levels of this antigen at different times in the underlying conditions and the stimulation of GPI-PLD activity with suramina were compared. In particular, CEA release was increased in Suramin-induced cells relative to the control cells, as it was observed to be greater than that observed due to the effect on the GPI-PLD (Figures $3 a$ and $3 b$ ). The difference between the control cells and the affected cells of suramina is indicated after 
(a)
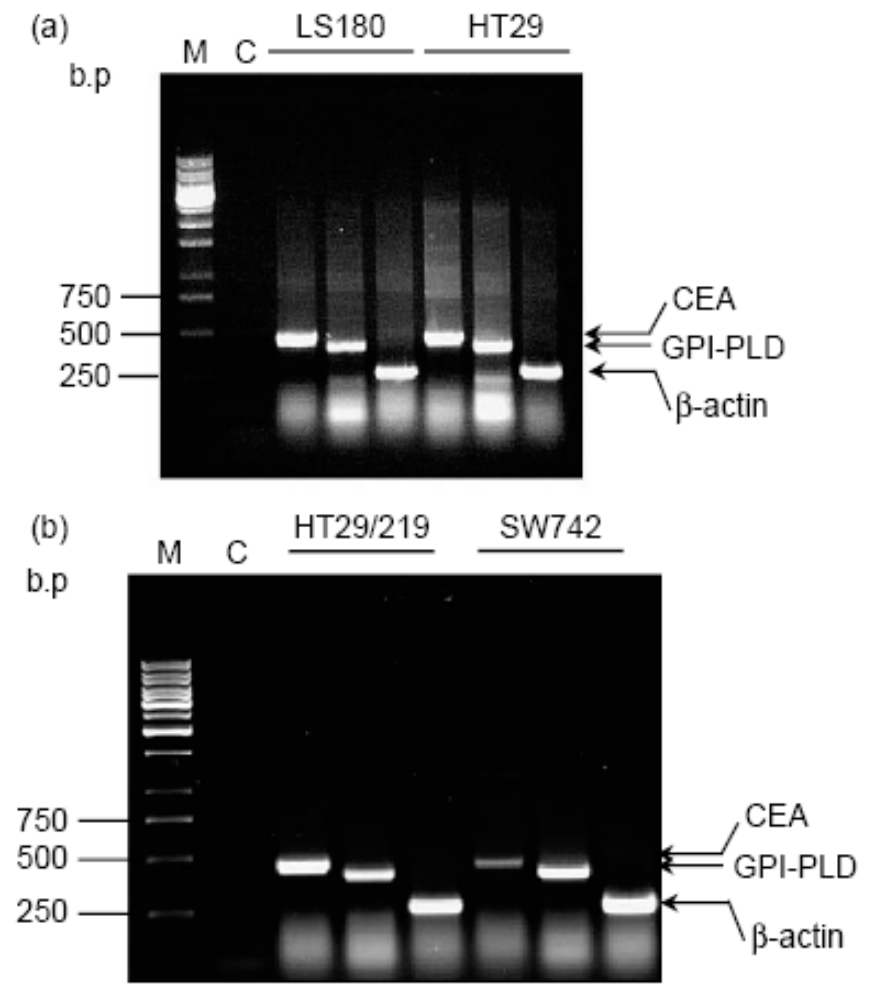

Figure 2. Electrophoresis with carcinoma ambrionic antigens, GPI-PLD and RT-PCR actin- $\beta$ in agglutinin-carcinoma lines of Ls-180 and HT-29 (in Figures a), SW742 and HT29/219 (in Figure b) and staining with ethydiamide.

2 hours of incubation of the cells in the serum medium (Figure 3a). When the cells were exposed to $100 \mu \mathrm{g} / \mathrm{ml}$ of Soram for 4 hours, the release of their carcinoma ambrionic antigen increased $79 \%$ compared to control cells. However, it decreases afterwards, which is probably due to a decrease in the overall content of CEA within the cell. This increase in the antigen release was not due to the loss of cell integrity, since the staining of cells with trypan blue showed that the number of live cells did not differ in both samples. The effect of surfamine on the release of carcinoma-embryonic antigen into the serum-free enzyme was reduced in comparison with the serum medium (Figure $3 \mathrm{~b}$ ), which may be due to lower biosynthesis in non-serum conditions. In general, all data show that Suramin can significantly increase the release of CEA from cells of both types of environments. Since suramina does not release the measurable carcinoma-embryonic antigen values from the poorly-produced HT-29 cells, it can be concluded that suramina only stimulates the release of carcinoma-embryonic antigen and not its biosynthesis. Although Soramyn is a non-specific activator for GPI-PLD and has pliotropic effects on many enzymatic systems and on growth-receptor factor interactions, the concurrent GPI-PLD activator and inhibitor results match the GPI cutting mechanism. It has been shown that carcinoma embryonic secretion of the antigen is related to the distinction that suramina occurs in human colon cancer cells [31]. The incubation of HT-29 and Moser cells for 4 days with a concentration of Sur-Amine IC-50 causes differentiation and secretion of CEA from these cells. The same effect of Surinam on SNU-16 human stomach cancer cell line has been shown [32]. Ls-180 is not a differentiating cell line. Our results showed that, even if the cells were under the influence of surinam for a short time ( 2 hours), the carcinogenic embryonic secretion of the antigen would be high. Therefore, it seems that the effect of suramina on this antigen is a process independent of stimulation of cellular differentiation.

\section{Effect of GPI-PLD inhibitor on carcinogenic embryonic secretion of antigen}

The GPI-PLD enzyme is inhibited by 1,10-phenanthraine (PNT). This compound is a chelator for biphasic cations that inhibit phospholipase enzymes of type GPI-PLD and not type C (22 and 21). The Ls-180 cells were incubated with PNT values of $2-10 \mathrm{~g} / \mathrm{ml}$. Concentrations higher than $4 \mu \mathrm{g} / \mathrm{ml}$ of PNT caused cell toxicity, so the concentration of $2 \mathrm{~g} / \mathrm{ml}(10 \mu \mathrm{M})$ of PNT was used in subsequent experiments. The cells of Ls-180 were placed in the presence and absence of 2 PNT $\mathrm{g} / \mathrm{ml}$ in a medium with and without serum for 2-4 hours. The effect of this specific GPI-PLD inhibitor on the secretion of carcinoma ambrionic antigen from Ls-180 cells was measured and the CEA values were measured in the medium. In these healthy cells, the addition of a chelator of strong binomial cations (PNTs) strongly inhibits the release of this antigen. This effect is more pronounced in a serum-free environment, probably due to the interaction of PNT with serum cations. The concentration of carcinogenic embryonic serumfree enzyme-linked antigens is two times lower than that of the control group. A decrease of $18 \%$ and $12.5 \%$ in antigen release was observed after 4 and 2 hours incubation in serum-free plus PNT, respectively.
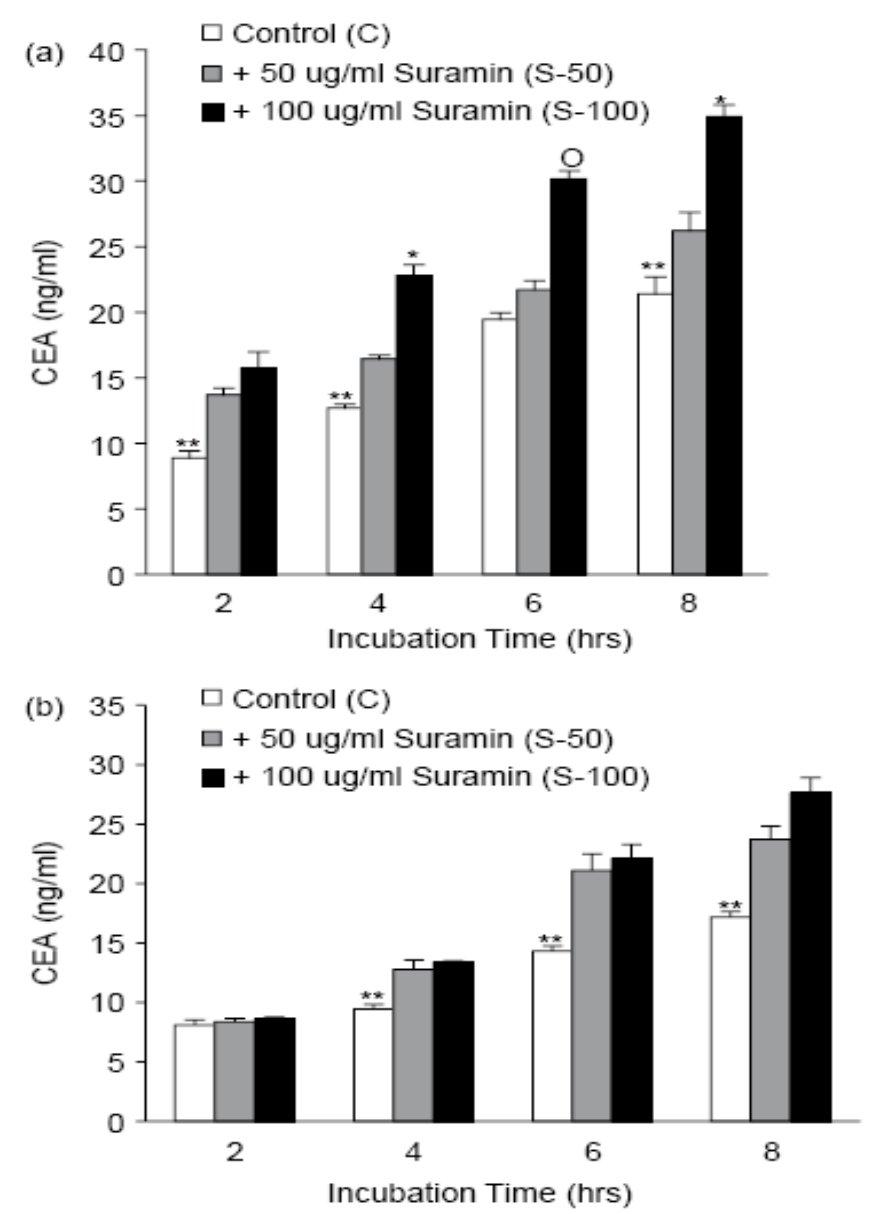

Figure 3. Effect of GPI-PLD activator (Suramin) on the release of carcinomaembryonic antigen from Ls-180 The Ls-180 cells were cultured in 4-bed plates and were exposed to (a) and (a) and for a period of 8-2 hours at concentrations of $50(\mathrm{~S}-50)$ and $100(\mathrm{~S}-100) \mu \mathrm{g} / \mathrm{ml}$ of sulamine and medium Lacked (b) my head. The carcinoma-embryonic level of the released antigen was measured by commercial ELISA kits. The cell culture medium without this chemical was used as a control. The test results show the standard mean error in two independent studies. Statistical differences between groups by tukey HSD multiple comparison test. 
The data are obtained 2 times with two independent tests, and the mean values of all experiments are shown in Figure 4. After 4 hours staining with Trypan Blue, no difference was observed in the survival of the cells. Because PNT, GPI-PLD and not GPI-PLC are inhibited [22,23,33], the inhibitory effect of PNT on the release of the carcinogenic ambrionic antigen from Ls- 180 cells can be seen as another indication of the ineffectiveness of GPI-specific PLCs in CEA release is used. The GPI$\mathrm{PLD}$ is connected with a $\mathrm{Zn}+2$ ion and this cathion is essential for its function [33]. PNT is a $\mathrm{Zn}$ chelator and it has been shown that its effect on mammalian GPI-PLD is reversed by the addition of $\mathrm{ZnCl} 2$ [34]. To investigate whether $\mathrm{ZnCl} 2$ could reverse the inhibitory effect of PNT on the release of carcinoembryonic antigens, we used $2 \mathrm{~g} / \mathrm{ml} \mathrm{PNT}$ plus $12 \mu \mathrm{m} \mathrm{ZnCl} 2 \mu \mathrm{M}$. As expected, $\mathrm{ZnCl} 2$ reversed the weak release of CEA during incubation with the PNT. As can be seen, the release of carcinoma ambrionic antigen returns to values above the control, which indicates that $\mathrm{Zn}+2$ can also liberate this antigen Stimulates (Figure 4). 2-hour incubation with $\mathrm{Zn}+2$ has a CEA release of 3 and 1.4 times, respectively, in comparison with PNT in the absence and serum environment. Adding $\mathrm{ZnCl} 2$ alone and not $\mathrm{MgCl} 2$ to the culture
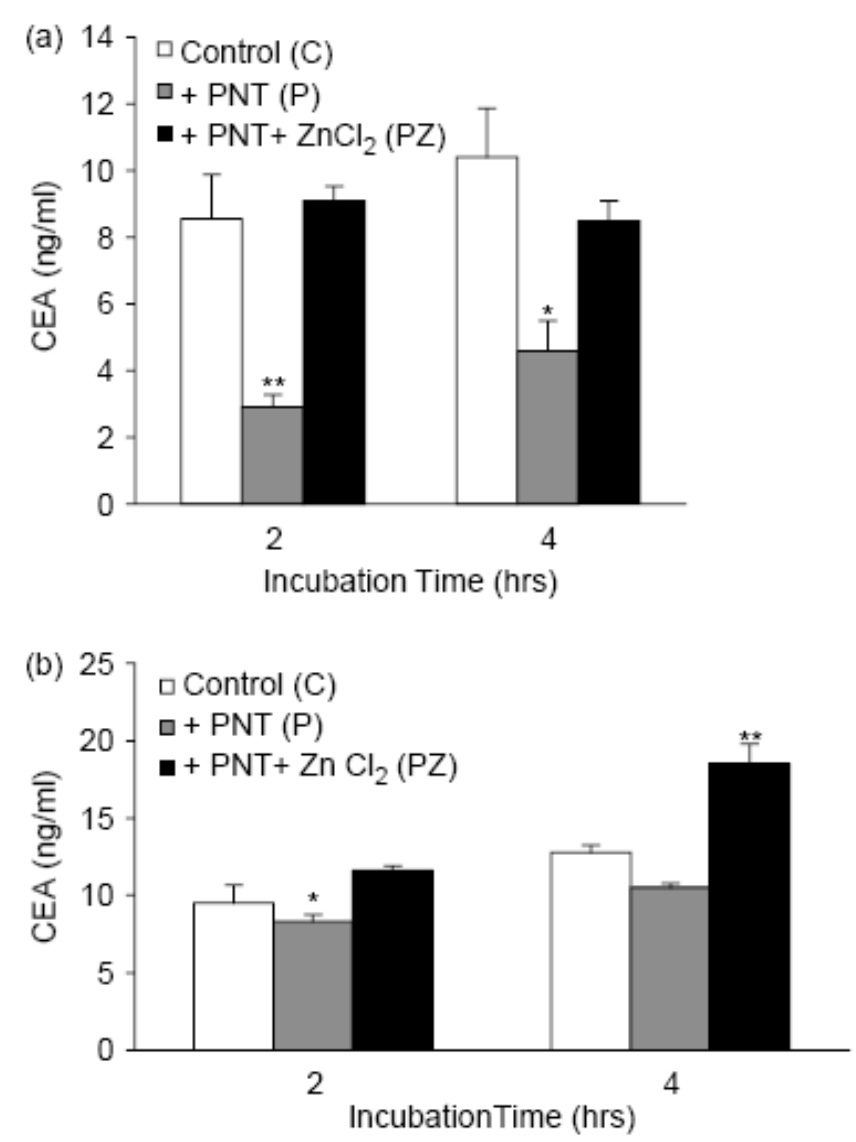

Figure 4. Effect of PNT, an inhibitor of GPI-PLD, on the release of carcinogenic ambrionic antigen in the culture medium of Ls-180 cells. The cells were cultured in 4-bed plates until the sub-confluency stage, and then $2 \mu \mathrm{g} / \mathrm{ml}$ PNT (P) or $2 \mu \mathrm{g} / \mathrm{ml}$ PNT plus Mn 5/12 ZnCl2 $(\mathrm{p}+\mathrm{z})$ into a medium lacking (a) and having B) My serum was added. As stated in Section 2 , the amount of CEA released in the environment was measured. The environment of the cells that were not subjected to any chemical was used as control. The results are presented as a mean and standard error of two independent tests. The statistical differences between the two groups were calculated using the Tukey HSD test. (A) * significant P-value vs. C, significant $\mathrm{P}$-value vs. $\mathrm{C}$ and $\mathrm{PZ} * *,(\mathrm{~b}) * \mathrm{PZ}$ significant $\mathrm{P}$-value vs. ** significant $\mathrm{P}$-value vs. $\mathrm{C}$ and $\mathrm{P}$. medium increases the specific release of carcinogenic embryonic antigens from these cells. As a result, we showed that PNT interferes with the autoimmune embryonic antigen from healthy cells Ls-180, but this reduction in release is compensated by $\mathrm{ZnCl} 2$. It suggests that in a serum-free and in the presence of Suramin and PNT, the release of carcinoma-embryonic antigens increases and decreases, the release of the antigen is catalyzed by the GPI-PLD endogenous. Several studies have shown that PNT, a chelator of metal ions, has a potent inhibitor of Ca 2+, a more effective inhibitor of GPI-PLD than EDTA or EGTA $[22,34,35]$. To confirm the specific effect of PNT on the release of CEA, we investigated the effect of EDTA (a non-specific chelator for $\mathrm{Ca}+$ 2 and other ions) on its release. As shown in Figure 5, when adding EDTA at concentrations of 10 and $25 \mu \mathrm{M}$ to the culture medium of Ls180 cells, there is little effect on the release of the carcinoma embryonic antigen. Therefore, the inhibitory effect of PNT on the release of CEA is even more specific than the higher concentrations of EDTA. Although our GPI-PLD enzyme was not purified in our experiment, however, this active and inactive pattern is consistent with the GPI-PLD mechanism of cutting $[22,23,36]$.

\section{Conclusion}

CEA is associated with colorectal malignancies, and is useful for identifying repeated malignancies. The difference between the level of the carcinoma and embryonic antigen and its tumors in some cancer patients may be due to the activation of the selected enzyme responsible for the release of the antigen. GPI-anchored proteins like carcinoma embryonic antigens are easily cut through the addition of exogenous bacterial PI-PLC enzymes, although this enzyme is not specific to GPI. This study is the first study to suggest that endogenous GPI-PLD plays a role in the release of this antigen from colorectal carcinoma cells. The exact GPI-PLD cell location and the GPI-anchor cutting location that is either cell-level or intracellular is still unknown $[29,37,38]$. Therefore, CEA is either free from cell surface or intracellular, and is unclear. The relationship between the increase of carcinoma embryonic antigen and the progression of malignant cancer is not completely clear. The GPIanchored CEA and/or CEACAM6 (which is another member of the carcinoembryonic antigen family) is distinctly different from that of the TM-linked CEA family, and this difference is due to the fact that an increase in the uncontrolled expression of the first group has stopped the differentiation of many. The cells become colonocytes [19]. Initial studies have shown that GPI-PLD plays a role in signal transduction. The cutting and release of GPI proteins by GPI-PLD promotes the release of mediators of the signaling cascade by phosphatidic acid and diacylglycerol [39]. The presence of carcinoembryonic antigens and GPI-PLDs on the surface of the carcinoma cells is interesting because it offers the potential for the production of secondary propagandas that have an intracellular role. Therefore, it would be interesting to find out the relationship between the degree of differentiation and GPI-PLD enzyme activity in these cells.

In this study, we investigated the self-release mechanism of CEA in human colon cancer cells. In some of these cells, we changed the expression of the GPI-PLD enzyme. Using the activator and inhibitor of this enzyme, we showed that in the cancer cells of the colon of the Ls-180 line, the release of this antigen increases and decreases, respectively. Understanding the mechanism for the release of carcinogenic embryonic antigens can help in the diagnosis and control of cancer patients [19]. 

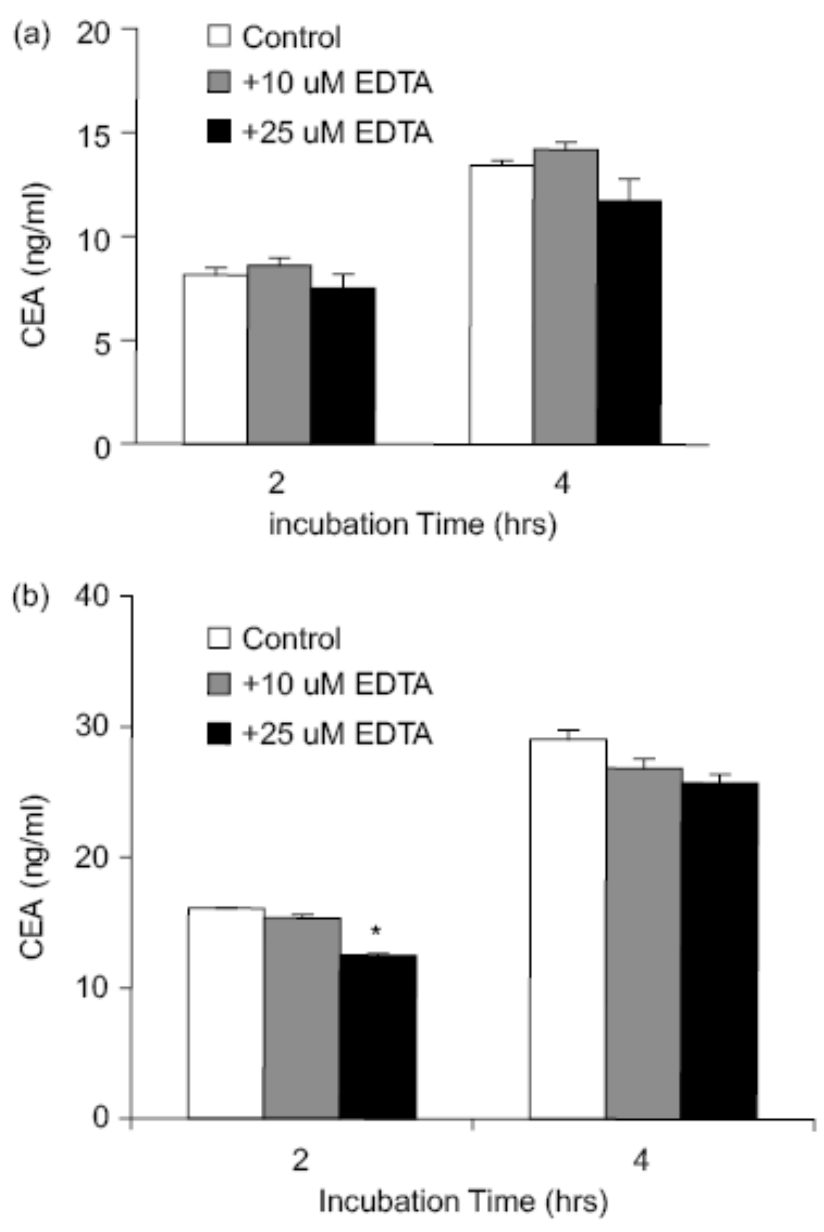

Figure 5. Effect of EDTA on the release of carcinoma embryonic antigen in the culture medium of Ls-180 cells. The cells were cultured in a 6 -cm plates for sub-confluency, and then 10 and 25 EDTA were added in $2 \mathrm{ml}$ of medium (a) and serum (b) was added. The amount of released CEA as measured in the text was measured. The environment of the cells that were not subjected to any chemical was used as control. The results are presented as a mean and standard error of two independent tests. The statistical differences between the two groups were calculated using the Tukey HSD test.

\section{References}

1. Pihl E, Nairn RC, Hughes ES, Cuthbertson AM, Rollo AJ (1980) Mucinous colorectal carcinoma: immunopathology and prognosis. Pathology 12: 439-447.

2. Wagener C, Muller-Wallraf R, Nisson S, Groner J, Breuer H (1981) Localization and concentration of carcinoembryonic antigen (CEA) in gastrointestinal tumors: correlation with CEA levels in plasma. J Natl Cancer Inst 67: 539-547. [Crossref]

3. Goslin R, O'Brien MJ, Steele G, Mayer R, Wilson R, et al. (1981) Correlation of Plasma CEA and CEA tissue staining in poorly differentiated colorectal cancer. Am J Med 71: 246-253. [Crossref]

4. Hefta SA, Hefta LJ, Lee TD, Paxton RJ, Shively JE (1988) Carcinoembryonic antigen is anchored to membranes by covalent attachment to a glycosylphosphatidylinositol moiety: identification of the ethanolamine linkage site. Proc Natl Acad Sci USA 85: 4648-4652. [Crossref]

5. Tibbetts LM, Doremus CM, Tzanakakis GN, Vezeridis MP (1993) Liver metastases with 10 human colon carcinoma cell lines in nude mice and association with carcinoembryonic antigen production. Cancer 71: 315-321. [Crossref]

6. Zhou H, Fuks A, Stanners CP (1990) Specificity of intercellular adhesion mediated by various members of the immunoglobulin supergene family. Cell Growth Differ 1: 209-215. [Crossref]

7. Screaton RA, Penn LZ, Stanners CP (1997) Carcinoembryonic antigen, a human tumor marker, cooperates with Myc and Bcl-2 in cellular transformation. J Cell Biol 137: 939-952. [Crossref]
8. Edmiston KH, Gangopadhyay A, Shoji Y, Nachman AP, Thomas P, Jessup JM (1997) In vivo induction of murine cytokine production by carcinoembryonic antigen. Cancer Res 57: 4432-4436. [Crossref]

9. Gangopadhyay A, Lazure DA, Thomas P (1998) Adhesion of colorectal carcinoma cells to the endothelium is mediated by cytokines from CEA stimulated Kupffer cells. Clin Exp Metastasis 16: 703-712. [Crossref]

10. Minami S, Furui J, Kanematsu T (2001) Role of carcinoembryonic antigen in the progression of colon cancer cells that express carbohydrate antigen. Cancer Res 21: 2732-2735. [Crossref]

11. Jean F, Malapert P, Rougon G, Barbet J (1988) Cell membrane but not circulating, carcinoembryonic antigen is linked to a phosphatidylinositol-containing hydrophobic domain. Biochem Biophys Res Commun 155: 794-800. [Crossref]

12. Khan WN, Hammarström S (1991) Biosynthesis of carcinoembryonic antigen (CEA) gene family members expressed in human tumor cell lines: evidence for cleavage of the glycosyl phosphatidyl inositol (GPI) anchor by GPI-PLC and GPI-PLD. Biochem Int 25: 723-731. [Crossref]

13. Kinugasa T, Kuroki M, Yamanaka T, Matsuo Y, Oikawa S, et al. (1994) Non-proteolytic release of carcinoembryonic antigen from normal human colonic epithelial cells cultured in collagen gel. Int J Cancer 58: 102-107. [Crossref]

14. Metz CN, Brunner G, Choi-Muira NH, Nguyen H, Gabrilove J, et al. (1994) Release of GPI-anchored membrane proteins by a cell-associated GPI-specific phospholipase D. Eur Mol Biol Org J 13: 1741-1751. [Crossref]

15. Lierheimer R, Kunz B, Vogt L, Savoca R, Brodbeck U, Sonderegger P (1997) The neuronal cell-adhesion molecule axonin-1 is specifically released by an endogenous glycosylphosphatidylinositol-specific phospholipase. Eur J Biochem 243: 502-510. [Crossref]

16. Wilhelm OG, Wilhelm S, Escott GM, Lutz V, Magdolen V, et al. (1999) Cellular glycosylphosphatidylinositol-specific phospholipase D regulates urokinase receptor shedding and cell surface expression. J Cell Physiol 180: 225-235. [Crossref]

17. Tsang TC, Fung WJ, Levine J, Metz CN, Davitz MA, et al. (1992) Isolation and expression of two human glycophosphatidylinositol phospholipase D (GPI-PLD) cDNAs. Fed Am Soc Exp Biol J 6: 1922.

18. MG Low (2000) Structure and function of GPI-specific phospholipases in: NG Young, J Moss (Eds.). PNH and the GPI-Linked proteins, Academic Press: San Diego CA, p. 239-268.

19. Ilantzis C, DeMarte L, Screaton RA, Stanners CP (2002) Deregulated expression of the human tumor marker CEA and CEA family member CEACAM6 disrupts tissue architecture and blocks colonocyte differentiation. Neoplasia 4: 151-163. [Crossref]

20. Bradford MM (1976) A rapid and sensitive method for the quantitation of microgram quantities of protein utilizing the principle of protein-dye binding. Anal Biochem 72: 248-254. [Crossref]

21. Chomczynski P, Sacchi N (1987) Single-step method of RNA isolation by acid guanidinium thiocyanate-phenol-chloroform extraction. Anal Biochem 162: 156-159. [Crossref]

22. Huang KS, Li S, Fung WJ, Hulmes JD, Reik L, et al. (1990) Purification and characterization of glycosylphosphatidylinositol-specific phospholipase D. J Biol Chem 265: 17738-17745.

23. Low MG, Prasad AR (1988) A phospholipase D specific for the phosphatidylinositol anchor of cell-surface proteins is abundant in plasma. Proc Natl Acad Sci U S A 85: 980-984. [Crossref]

24. Low MG, Huang KS (1991) Factors affecting the ability of glycosylphosphatidylinositolspecific phospholipase D to degrade the membrane anchors of cell surface proteins. Biochem J 279: 483-493. [Crossref]

25. Deng JT, Hoylaerts MF, De Broe ME, van Hoof VO (1996) Hydrolysis of membranebound liver alkaline phosphatase by GPI-PLD requires bile salts. Am J Physiol 271: G655-663. [Crossref]

26. Sack TL, Gum JR, Low MG, Kim YS (1988) Release of carcinoembryonic antigen from human colon cancer cells by phosphatidylinositol-specific phospholipase C. $J$ Clin Invest 1988; 82: 586-593. [Crossref]

27. Xiaotong H, Hannocks MJ, Hampson I, Brunner G (2002) GPI-specific phospholipase D mRNA expression in tumor cells of different malignancy. Clin Exp Metastasis 19: 291-299. [Crossref]

28. Deeg MA, Bierman EL, Cheung MC (2001) GPI-specific phospholipase D associates with an apoA-I- and apoA-IV-containing complex. J Lipid Res 42: 442-451. [Crossref] 
29. Lee JY, Kim MR, Sok DE (1998) Enzymatic release of $\mathrm{Zn}+2$ glycerophosphocholine cholinephosphodiesterase from brain membranes by glycosylphosphatidylinositolspecific phospholipases and its regulation. Neurochem Res 23: 899-905. [Crossref]

30. Kristiansen S, Richter EA (2002) GLUT4-containing vesicles are released from membranes by phospholipase D cleavage of a GPI anchor. Am J Physiol Endocrinol Metab 283: E374-E382. [Crossref]

31. Reynolds S, Rajagopal S, Chakrabarty S (1998) Differentiation-inducing effect of retinoic acid, difluoromethylornithine, sodium butyrate and sodium suramin in human colon cancer cells. Cancer Lett 134: 53-60. [Crossref]

32. Choe G, Kim WH, Park JG, Kim YI (1997) Effect of suramin on differentiation of human stomach cancer cell lines. J Korean Med Sci 12: 433-442. [Crossref]

33. Park SW, Choi K, Kim IC, Lee HH, Hooper NM, Park HS (2001) Endogenous glycosylphosphatidylinositol specific phospholipase $\mathrm{C}$ releases renal dipeptidase from kidney proximal tubules in vitro. Biochem J 353: 339-344. [Crossref]

34. Li JY, Hollfelder K, Huang KS, Low MG (1994) Structural features of GPI-specific phospholipase $\mathrm{D}$ revealed by proteolytic fragmentation and $\mathrm{Ca}+2$ binding studies. $J$ Biol Chem 269: 28963-28971.
35. Li JY, Low MG (1999) Studies of the role of the integrin EF-hand, Ca+2 -binding sites in glycosylphosphatidylinositol-specific phospholipase D: reduced expression following mutagenesis of residues predicted to bind $\mathrm{Ca}+2$. Arch Biochem Biophys 361: 142-148.

36. Davitz MA, Hom J, Schenkman S (1989) Purification of a glycosyl-phosphatidylinositolspecific phospholipase D from human plasma. J Biol Chem 264: 13760-13764. [Crossref]

37. Hari T, Kunze H, Bohn E, Brodbeck U, Butikofer P (1996) Subcellular distribution of glycosylphosphatidylinositol-specific phospholipase D in rat liver. Biochem $J 1996$; 320: 315-319.

38. Brunner G, Metz CN, Nguyen H, Gabrilove J, Patel SR (1994) An endogenous glycosylphosphatidylinositol-specific phospholipase D releases basic fibroblast growth factor-heparan sulfate proteoglycan complexes from human bone marrow cultures. Blood 83: 2115-2125. [Crossref]

39. Tsujioka H, Takami N, Misumi Y, Ikehara Y (1999) Intracellular cleavage of glycosylphosphatidylinositol by phospholipase $\mathrm{D}$ induces activation of protein kinase C alpha. Biochem J 342: 449-455. [Crossref]

Copyright: (C2017 Asadi S. This is an open-access article distributed under the terms of the Creative Commons Attribution License, which permits unrestricted use, distribution, and reproduction in any medium, provided the original author and source are credited. 